Uşak Üniversitesi Sosyal Bilimler Dergisi

$2015,8 / 2$

\title{
Üniversite Öğrencilerinin Sigara Kullanımını Etkileyen Faktörler (Ekonometrik Bir Yaklaşım)
}

Şadan ÇALIŞKAN*

\section{$\ddot{O} z$}

Sigara kullanımı, toplum sağlığı açısından son derece zararlı ve yaygın bir alışkanlıktır. Bu nedenle, sigara kullanımı tüm dünyada olduğu gibi ülkemizde de gündemden hiç düşmeyen ve acil çözüm bekleyen çok önemli bir sorundur. Bu çalışmada, ülkemizin geleceğini oluşturan gençlerin özel bir bölümünü oluşturan üniversite öğrencilerinin sigara kullanma davranışlarını etkileyen faktörler, Uşak Üniversitesi öğrencilerine uygulanan anket formundan elde edilen kesitsel tipteki veriler kullanılarak ekonometrik tahmin yöntemiyle analiz edilmiştir.

Ekonometrik analizde öğrencilerin cinsiyetinin, alkol kullanma durumlarının, ailelerinde ve arkadaş çevrelerinde sigara içenlerin bulunmasının ve gelir düzeylerinin yükselmesinin sigara kullanma durumları üzerinde etkili olduğu belirlenmiştir. Öğrencilerin sigara içme olasılığını artıran en önemli faktörler olarak sırasıyla, arkadaş çevrelerinde sigara içenlerin bulunması, alkol kullanmaları ve ailelerinde sigara kullanan bireylerin bulunması belirlenmiştir. Ayrıca, öğrencilerin cinsiyetlerinin ve gelir düzeylerinin yükselmesinin de sigara kullanma davranışı üzerinde anlamlı farklılık oluşturan önemli faktörler arasında yer aldığı sonucuna da ulaşılmıştır.

Anahtar Kelimeler: Üniversite Öğrencisi, Sigara Kullanımı, Uşak Üniversitesi, Logit Model.

\section{The Factors Affecting Smoking of Undergraduates: An Econometric Approach}

\section{Abstract}

Smoking is an extremely harmful and widespread habit in terms of public health. Therefore, smoking is a major issue which needs an urgent solution in our country as well as all over the world. In this study, the factors which affecting the undergraduates' smoking behaviors analyzed by

* Doç. Dr., Uşak Üniversitesi, İktisadi ve İdari Bilimler Fakültesi, İktisat Bölümü, sadan.caliskan@usak.edu.tr 
using cross-sectional econometric methods. The data obtained from the Usak University undergraduates.

The findings of the study show that the factors determining the status of smoking such as gender, drinking alcohol, smoker relatives and income. Locating smokers between friend groups, drinking alcohol and smoker relatives have been identified as the most effective factors on increasing the possibility of smoking, respectively. Also gender and the higher levels of income are important factors on smoking status of undergraduates.

Key Words: Undergraduate, Smoking, Usak University, Logit Model.

\section{Giriş}

Sigara kullanımı, gerek yol açtığı sağlık sorunları gerekse sigara için yapılan harcamaların büyüklüğü nedeniyle tüm dünyada olduğu gibi ülkemiz için de çok önemli bir problemdir. Günümüzde bilimsel çevrelerce sigaranın insan sağlı̆̆ını tehdit eden en önemli faktörlerden birisi, hatta en önde geleni olduğu konusunda fikir birliği oluşmuştur. Sigara, üreticisinin önerdiği biçimde tüketildiğinde -kullanılan miktara bağlı olmaksızınkullanıcısının sağlığına zarar veren, yaşam kalitesini önemli ölçüde düşüren, ölümlere neden olabilen ve yasal olarak satılan tek üründür. Üstelik sigara kullanımı, önlenebilir ölüm nedenleri arasında birinci sırada yer almaktadır.

Sigara kullanımının bireylerin bedensel ve zihinsel sağlıklarını olumsuz etkilediği, eğitim performansından aile ilişkilerine, iş hayatına kadar pek çok alanda bireyleri olumsuz etkileyen bir alışkanlık olarak kabul edilmektedir. Günümüzde bireyler, toplumlar ve devletler sigaranın zararlarını tartışmayı bırakmış, sigara kullanımı ile etkin mücadelenin yöntemlerini ve hukuksal zemininin oluşturulmasına yönelik önlemleri tartışır hale gelmişlerdir. Ülkemizde son dönemde sigara kullanımı ile mücadele açısından son derece ileri düzenlemeler yapılmıştır. Sigara içilecek alanlar ve satış koşulları ile ilgili çok kapsamlı yasaklar getirilmiştir. Sigara reklâmları neredeyse tamamen yasaklanmıştır. Kanunla getirilen yasaklar ciddi maddi yaptırımlarla desteklenmiştir.

Sigara içicilerinin büyük çoğunluğu bu alışkanlığı çok büyük oranda gençlik yıllarında elde etmektedir. Yapılan saha çalışmaları da bu durumu teyit etmektedir. Örneğin, Burt ve Peterson (1998) yapmış oldukları çalışmada, sigara içicilerinin \%71'inin sigaraya 18 yaş veya altında başladığ 1 sonucuna ulaşmışlardır. Bu bağlamda, toplumların geleceğini oluşturan gençlerin sigaraya başlamasının önlemesi, içenlerin sigara bağımlılığından 
kurtarılması ve sigara içmeyen gençlerin pasif içiciliğin zararlı etkilerinden korunmasına yönelik çalışmalar önem kazanmıştır.

Bağımlılık yapan ve sağlık için önemli zararlı sonuçlara neden olan sigara ve alkol gibi ürünlerin tüketim miktarını sadece ekonomik faktörlerle açıklamak mümkün değildir. Bağımlılık etkisinden dolayı, özellikle tiryaki seviyesinde bağımlılık kazanmış bir sigara kullanıcısı için kullanılan sigara miktarının sigaranın fiyatındaki ve gelirdeki değişmelere çok fazla duyarlı olmadığı bilinmektedir. Bu nedenle, sigara fiyatlarının yükselmesi ya da sigara tiryakisinin gelirindeki azalmanın kullanım miktarını önemli ölçüde azalttığını söylemek mümkün değildir.

Bağımlılık yapan tüm alışkanlıklar içinde belki de en tehlikelisi olduğu bilinmesine rağmen sigara kullanımı, özellikle gelişmekte olan ülkelerde giderek artmaktadır (Atılgan vd., 2008: 160). Gelişmiş ülkelerde sigara tüketimi azalmakta iken, gelişmekte olan ülkelerde sigara tüketimi artmaya devam etmektedir. Bu olumsuz gelişmenin en önemli nedeni uluslararası tütün şirketlerinin gelişmekte olan ülkelerdeki pazar oluşturma stratejileridir. Dünyada sigaraya başlama yaşının ortalama 11 yaşa kadar düştüğü göz önüne alındığında, sigara kullanımı ile mücadelede gençlerin bilgilendirilmesinin önemi daha iyi anlaşılmaktadır. Bağımlılık yapan zararlı maddelere başlama yaşının genellikle gençlik yılları içinde yer alması, bu sorunun aynı zamanda bir gençlik çağı sorunu olarak ele alınmasını da gerektirmektedir. Ne yazık ki genç yaşlarda sigaraya başlayanların çoğu sağlık açısından aldıkları risklerin bilincinde değildir (eczacibasisaglik.com.tr). Bu nedenle sigara ile mücadelenin gençlik çağındaki bireylerden başlaması gerekmektedir. Gelişmiş ülkelerde sigara içme oranının azalmakta olmasının temel nedenleri arasında 1960'lı yıllardan itibaren bu ülkelerde sigara ile mücadelede sıkı önlemlerin uygulamaya konulması (Göksel ve Diğerleri, 2001: 49-50) ve sigaranın zararları konusunda özellikle yetişkinler arasında belirli bir bilinç düzeyinin ortaya çıkması yer almaktadır.

\section{Sigaranın Kısa Tarihçesi}

Tütün tarımının Milattan Önce (M.Ö.) 6000'li yıllarda Amerika kıtasında başladığı ve M.Ö. 1500'lü yıllarda Orta Amerika'da yaşayan Mayalar'ın tütün kullandığı bilinmektedir. Mayalar kuru tütün yapraklarını sararak veya ufalayarak ilkel pipolarda kullanmışlardır. Tütün ayrıca sakız yapılarak, tütün tozları insan bedenine sürülerek veya lavman gibi yöntemlerle de kullanılmıştır. Tütün Avrupa'ya 1492 yılında Küba'ya ayak basan Christopher Columbus tarafından tanıtılmışır. Columbos Küba adasındaki yerlilerin dini törenlerde ve şölenlerde keyifle "Tobacos" olarak 
adlandırdıkları tütünü içtiğini görmüş ve dönüşünde tütünü Avrupa'ya taşımıştır. Amerika'ya göç eden Avrupalılar yeni kıtada ilk kez 1531 yılında tütün ekimine başlamışlardır. Ticari amaçla tütün tarımı ilk kez 1612 senesinde Virginia'da gerçekleştirilmiştir. Tütünün Avrupa'da yaygın biçimde kullanılmaya başlanması ise Fransa'nın Portekiz elçisi Jean Nicot sayesinde olmuştur. Elçi 1560 yılında Fransız Kralı II. Henry'nin ölmesiyle depresyona giren dul Kraliçe Catherine de Medicis'e tütün tohumu göndermiştir. Saray bahçesine ekilen tohumlar çiçek açtıktan sonra kraliçenin migren türü baş ağrısını geçirdiği için bu tarihten sonra tütünün keyif ve cesaret verici özelliklerinden başka ilaç olarak da etkili olduğu şeklinde Avrupa'da yaygın bir inanç oluşmuş ve kullanımı yaygınlaşmıştır. Hatta Sevilla Üniversitesi'nden Nocola Monardes, tütünün başta tüberküloz olmak üzere birçok hastalığa iyi geldiğini kitabında yazmıştır (Barış, 2002). Tütünün her türlü hastalığa deva olduğuna dair söylentiler kulaktan kulağa dolaşırken tütün kullanımı Avrupa'da hızla yaygınlaşmıştır.

Tütün önceleri puro ve pipo içinde kullanılırken, sonraları enfiye ve tütün sakızı olarak kullanılmaya başlanmıştır. Günümüzde puro, pipo, enfiye, nargile vb. türleri bulunmakla birlikte tüm dünyada egemen tüketim biçimi sigaradır ${ }^{1}$.

Osmanlı Devletinde 1600'lü yıllarda Balkanlar ve Ege bölgesinde tütün üretimi yaygınlaşmaya başlamakla birlikte; asıl tütün kullanımının yaygınlaşması 17. yüzyılda gerçekleşmiştir. Endüstriyel sigara üretimi ise 19.yüzyılın sonlarında başlamıştır. Osmanlı Devleti 1895 yılında Fransız Reji şirketiyle anlaşmış ve İstanbul, İzmir, Adana ve Samsun'da sigara fabrikaları kurulmuştur. Kurtuluş Savaşı'nın hemen başında Türkiye Büyük Millet Meclisi Hükümeti Reji şirketi ile anlaşmayı feshetmiş ve Tekel kurulmuştur. Türkiye'de üretilen şark veya yarı şark tipi tütün olup; daha çok Ege Bölgesi'nde, İzmir, Manisa, Aydın, Balıkesir; Karadeniz'de, Samsun, Trabzon ve Artvin civarında; Marmara ve Güney Doğu Anadolu'da üretilmektedir. Cumhuriyet Döneminde devlet, destekleme alımları ile tütün üretimini teşvik etmiş, halkın ürettiği tütünü, dış piyasadaki değerinden daha pahalı almıştır. 1986 yılında yürürlüğe giren bir yasa ile ülkemizde tütün tekeline son verilmiş, 1991 yılında çıkartılan bir kararname ile de yabancı şirketlerin Türkiye'de üretim tesisleri kurmalarına izin verilmiştir (www.fatihbasaran.com). Türkiye, önemli tütün üreticisi ülkeler arasında yar almakla birlikte tütün üretimini giderek azalmaktadır. Bu

\footnotetext{
${ }^{1}$ Bu çalışmada sigara kavramı, sigara ve diğer tüm tütün mamullerini ihtiva etmek üzere kullanılmıştır.
} 
gelişmede tütün tarımına yönelik desteklerin azaltılması ve sigara üretiminde daha fazla ithal tütün kullanımının rolü bulunmaktadır.

Gerek Osmanlı Devleti gerekse Cumhuriyet döneminde tütün istihdam, gelir, döviz ve vergi tahsilâtı gibi açılardan önemli bir tarımsal ürün olmuştur. Türkiye'de tütün üretimi yıllarca çok yüksek oranda desteklenmiştir. 2002 yılında Tütün Kanunu çıkıncaya kadar -bazı bölgesel kısıtlamalar dışında- üretilen tüm tütünlerin devlet tarafından satın alınması ve destekleme fiyatlarının yüksek tutulması tütün üretimin artmasına yol açmıştır. Hükümetlerin siyasi çıkarları uğruna izledikleri bu politika ekim alanı ve üretim miktarı konusunda önemli sorunlara neden olmuş, önemli miktarlarda ihtiyaç fazlası tütün elde kalmıştır. Ancak 24 Ocak 1980'de başlayan liberalleşme sürecinde tütün tarımına yönelik desteklemeler tedricen azaltılmıştır. 2000'li yılların başında tarımsal desteklemede doğrudan gelir desteğine geçilmesinden sonra tütün üretimine yönelik destekler iyice azalmıştır. Sigara tekelinin kaldırılmasından ve yabancı firmaların piyasa girmesinden sonra yerli tütün kullanımı azalırken yabancı sigaralar piyasaya hâkim olmaya başlamıştır (Uzun, 2010: 17-41).

\section{Sigara Kullanımının Başlıca Olumsuz Etkileri}

Sigara kullanımı, halk sağlı̆̆ı açısından ciddi sonuçları olan küresel bir sorundur. Bütün dünyada sigara ve diğer tütün mamullerinin tüketimdeki artışlar, aileler, yoksullar, ulusal sağlık sistemleri dolayısıyla ülkelerin ekonomileri üzerine ciddi yükler getirmektedir (Ergüder, 2008: 7). İnsanların sağlık ve yaşamlarına süre ve kalite olarak zarar veren en önemli etkenlerden biri olan sigara kullanımı insanların çalışma hayatını ve verimliliğini de olumsuz etkilemektedir.

Sigara içen kişiler, içmeyenlere göre daha sik hastalanmakta, hastalıklarını da sigara içmeyenlere göre daha şiddetli geçirmektedirler. Sigara içenlerin içmeyenlere göre hastalıklarının iyileşme süreleri daha uzun, hastanede yatış oranları daha yüksek ve yatış süreleri daha uzun dolayısıyla tedavi maliyetleri daha yüksektir. Hastalıkların seyrindeki bu olumsuzluk işe geri dönüş süreleri de artmaktadır. Bu durum genel yaşam kalitesini düşürdüğü gibi iş yaşamında ciddi kesintilere de neden olmakta ve ekonomik yaşam üzerinde olumsuz etkilere yol açmaktadır (eczacibasisaglik.com.tr). Hükümetler kamu sağlık harcamalarının büyümesine engel olmak dolayısıyla sosyal güvenlik sisteminin yükünü azaltmak için de sigara kullanımı ile mücadele etmek zorundadırlar.

Sigara, bir taraftan kullananların ve dumanına maruz kalanların sağlığını olumsuz etkilerken, diğer taraftan sigaradan kaynaklanan 
hastalıkların tedavi maliyetlerinin sosyal güvenlik sistemine verdiği zararlar nedeniyle sigara içmeyenler için de önemli bir ekonomik yük kaynağıdır.

Dünya Sağlık Örgütü (DSÖ) sigara kullanımını önlenebilir hastalık, sakatlık ve ölümlerin temel nedenlerinden birisi olarak kabul etmektedir. DSÖ'ne göre; sigara kullanımı dünyadaki en önemli sağlık sorunlarından birisini oluşturmaktadır. Dünyadaki en yaygın bağımlılık türü sigara kullanımıdır ve en önde gelen önlenebilir ölüm sebebidir. Tütün mamulleri, dünya çapında yaklaşık olarak her on yetişkin ölümünden birisinin nedenini oluşturmaktadır. Tütün mamullerinin zararlı etkileri nedeniyle her yıl yaklaşık 6 milyon kişi yaşamını yitirmektedir. DSÖ tahminlerine göre sigara kullanımından kaynaklanan hastalıklardan ölenlerin sayısı 2030 yılında 10 milyona ulaşacaktır. Sigaranın neden olduğu ölümlerin sayısı Türkiye'de 100 bin kişi civarında olup bu sayının 2030 yılında 240 bine ulaşması beklenmektedir (OECD, 2011: 50; Ergüder, 2008: 3).

Sigara kullanımının zararlı etkileri başlangıçtan itibaren görülmekle birlikte sigaranın zararları konusunun gündeme oturması 1939 yılında Amerika'da Ochsner'ın sigara ile akciğer kanseri arasında ilişki olduğunu ortaya koymasından sonra olmuş, 1964 yılında da Amerika Birleşik Devletleri sağlık otoriteleri sigaranın erkeklerde akciğer kanseri yaptığını ilan etmiştir. Ne var ki tütün ticareti olanca hızıyla artmış, tütün kullanımı giderek yaygınlaşmıştır (Barış, 2012: 2).

Tütün kullanımı bütün ülkeler açısından yaygın bir alışkanlık olmakla beraber tütün kullanımının yol açtığı sağlık sorunlarının ortaya konmasından sonra özellikle gelişmiş ülkelerde sigara kullanımında azalma görülmüştür. Gelişmiş ülkelerde satışları düşen sigara üreticileri ürünlerini satabilmek için yeni pazarlar aramaya başlamışlar, tütün kullanımının fazla olmadığı gelişmekte olan ülkelere yönelmişlerdir. Bunun sonucunda gelişmekte olan ülkelerde de sigara kullanımı hızla artmıştır (Ergüder, 2008: 8). DSÖ verilerine göre dünyada sigara içen 1,3 milyar kişinin $\% 84^{\prime} \ddot{u}$ ülkemiz gibi gelişmekte olan ülkelerde yaşamaktadır.

Sigara kullanımı, erken doğumların, dolaşım sistemi ile ilgili hastalıkların, kanser, kalp krizi ve diğer kalp hastalıkları, felç, akciğer kanseri, gırtlak ve ağız kanseri, pankreas kanseri gibi hastalıkların başlıca nedenini oluşturmaktadır. Sigara kullanımı ayrıca damar hastalıkları ve hipertansiyona da yol açmaktadır. Sigara kullanımı solunum sistemi hastalıklarının, hamilelerde eksik kilolu doğumların ve bebek hastalıklarının da temel nedenleri arasında yer almaktadır (OECD, 2001: 50).

Sigara içiciliği sadece içen kişilere zarar vermekle kalmaz, aynı zamanda etrafta bulunan bireylere ve çevreye de pek çok zarar verir. Eşi, sigara içen kadınlarda kanser riskinin arttığı ve tüm akciğer kanserlerinin 
Sosyal Bilimler Dergisi 29

\%20-30'unun çevresel sigara dumanından kaynaklandığı iddia edilmektedir. Aşırı sigara dumanına maruz kalan kişilerin kalp damar hastalığına yakalanma riskleri \%30-50 oranında artmaktadır. Sigara içmeyen kişilerin başkalarının içtiği sigara dumanını solumaları "pasif sigara içiciliği" adlandırılmaktadır. Sigara içimi yalnız içene değil, aynı ortamda bulunanlara da zarar vermesi ve bu durumdan en çok çocukların etkilenmesi bakımından önemli bir halk sağlığı sorunudur. Çocukların çevresel sigara dumanına maruz kalmasının akciğerin gelişimini negatif etkilediği, solunum sistemi enfeksiyonları, orta kulak enfeksiyonları ve çocukluk çağı astımı gibi hastalıkların görülme riskini arttırdığı belirlenmiştir (eczacibasisaglik.com.tr).

\section{Türkiye'de Sigara Tüketimi}

Türkiye'de sigara tüketiminin yaygınlığını belirlemek amacıyla çok sayıda çalışma yapılmıştır. Ancak bunların çoğu mikro ölçekte ve saygınlığı yüksek, gençler tarafından örnek alınma ihtimali yüksek öğretmen, doktor gibi belli başlı bazı meslek gruplarında sigara kullanma oranını belirlemek ve dikkatleri bu mesleklere yöneltmek amacıyla yapılmıştır. Ulusal ölçekte yapılan çalışmaların başında Küresel Yetişkin Tütün Araştırması (KYTA) ve Küresel Gençler Tütün Araştırması gelmektedir.

Tablo 1. Türkiye'de Yetişkinlerin Tütün ve Tütün Mamulü Kullanma Oranı, 2008, 2012

\begin{tabular}{|c|c|c|c|c|c|c|}
\hline \multirow{2}{*}{} & \multicolumn{2}{|c|}{ Her gün } & \multicolumn{2}{c|}{ Ara sıra } & \multicolumn{2}{c|}{$\begin{array}{c}\text { Şu anda } \\
\text { kullanmiyor / Hiç } \\
\text { kullanmamış }\end{array}$} \\
\hline & $\mathbf{2 0 0 8}$ & $\mathbf{2 0 1 2}$ & $\mathbf{2 0 0 8}$ & $\mathbf{2 0 1 2}$ & $\mathbf{2 0 0 8}$ & $\mathbf{2 0 1 2}$ \\
\hline Toplam & 27,4 & 23,8 & 3,9 & 3,3 & 68,7 & 72,9 \\
\hline -Erkek & 43,8 & 37,3 & 4,1 & 4,1 & 52,1 & 58,5 \\
\hline -Kadın & 11,6 & 10,7 & 3,6 & 2,4 & 84,8 & 86,8 \\
\hline Kent & 28,9 & 25,7 & 4,1 & 3,3 & 67,0 & 70,9 \\
\hline -Erkek & 43,9 & 38,9 & 3,9 & 4,1 & 52,2 & 56,9 \\
\hline -Kadın & 14,5 & 13,0 & 4,2 & 2,6 & 81,3 & 84,4 \\
\hline Kır & 23,9 & 18,9 & 3,3 & 3,1 & 72,8 & 77,9 \\
\hline -Erkek & 43,6 & 33,3 & 4,5 & 4,2 & 51,9 & 62,5 \\
\hline -Kadın & 5,0 & 4,7 & 2,2 & 2,0 & 92,8 & 93,2 \\
\hline
\end{tabular}

Kaynak: Küresel Yetişkin Tütün Araştırması, 2008, 2012. 
TÜIK tarafından yapılan 2012 KYTA verilerine göre, 15 yaş ve üzerindeki yetişkinlerin \%27'si sigara kullanmaktadır. Bu oran kadınlarda $\% 13$ iken erkeklerde \%41 olarak bulunmuştur. Kentsel alanla sigara içme oranı \%29 iken, kırsal alanda bu oran \%21'dir.

2008 ve 2012 Küresel Yetişkin Tütün Araştırmaları karşılaştırıldığında özetle aşağıdaki sonuç ve değerlendirmelere ulaşmak mümkündür;

-Günlük sigara içen yetişkin oranında düşme eğilimine girilmiştir. Günlük kullanan yetişkinlerin oranı \%27,4'ten, \%23,8'e düşmüştür. Diğer bir ifadeyle Türkiye'de sigara içenlerin oranında yaklaşık 2008'den 2012'ye $\% 13$ 'lük bir azalma meydana gelmiştir.

-Kır, Kent ve cinsiyet farkı olmaksızın Türkiye'de sigara kullananların oranı düşmüştür. Tüm gruplarda erkeklerde sigara kullanımındaki düşüş kadınlardan daha yüksektir. Erkeklerde sigara içenlerin oranı bu dönemde \%15 azalırken, kadınlarda \%8'lik bir azalma ortaya çıkmıştır. $(\% 21)$.

-Sigara içme oranındaki en önemli düşüş kırda gerçekleşmiştir

-Sigara içme oranındaki en önemli düşüş yaklaşık \%24'lük azalma ile kırsal kesim erkeklerde ortaya çıkmıştır.

-Kentlerde sigara kullanan yetişkinlerin oranı kırdan daha yüksektir.

-Hem kentte hem de kırsal kesimde cinsiyete göre sigara kullanım oranı kadınlara göre erkeklerde oldukça yüksektir.

-Kırsal kesimde 2008'den 2012'ye sigara kullanma oranında kırda erkeklerde belirgin bir düşüş yaşanmasına rağmen kadınlarda oldukça stabil bir durum gözlenmektedir. 
Tablo 2. Yaş Gruplarına Göre Bireylerin Her gün veya Ara Sıra Tütün Kullanma Oranı, 2008, 2012 (15 Yaş ve Üzeri) (\%)

\begin{tabular}{|c|c|c|c|c|c|c|}
\hline & \multicolumn{2}{|c}{ Türkiye } & \multicolumn{2}{c|}{ Kent } & \multicolumn{2}{c|}{ Kır } \\
\hline & $\mathbf{2 0 0 8}$ & $\mathbf{2 0 1 2}$ & $\mathbf{2 0 0 8}$ & $\mathbf{2 0 1 2}$ & $\mathbf{2 0 0 8}$ & $\mathbf{2 0 1 2}$ \\
\hline Toplam & 31,3 & 27,0 & 33,0 & 29,0 & 27,2 & 22,0 \\
\hline -Erkek & 47,9 & 41,4 & 47,8 & 43,0 & 48,1 & 37,5 \\
\hline -Kadın & 15,2 & 13,1 & 18,7 & 15,5 & 7,2 & 6,7 \\
\hline $\mathbf{1 5 - 2 4}$ & 25,4 & 18,9 & 25,6 & 19,4 & 24,8 & 17,4 \\
\hline -Erkek & 39,7 & 31,2 & 38,8 & 32,0 & 41,9 & 29,4 \\
\hline -Kadın & 11,7 & 6,8 & 13,0 & 7,6 & 8,4 & 4,4 \\
\hline $\mathbf{2 5 - 3 4}$ & 40,3 & 34,9 & 42,3 & 36,5 & 34,4 & 29,2 \\
\hline -Erkek & 58,0 & 53,1 & 58,4 & 55,4 & 57,0 & 45,3 \\
\hline -Kadın & 22,4 & 16,5 & 26,3 & 17,7 & 11,1 & 12,3 \\
\hline $\mathbf{3 5 - 4 4}$ & 39,6 & 36,2 & 40,3 & 37,4 & 37,7 & 32,8 \\
\hline -Erkek & 58,4 & 50,9 & 56,9 & 50,4 & 62,2 & 52,4 \\
\hline -Kadın & 20,5 & 21,4 & 23,6 & 24,5 & 11,9 & 11,7 \\
\hline $\mathbf{4 5 - 5 4}$ & 32,3 & 31,0 & 34,0 & 33,5 & 28,3 & 24,6 \\
\hline -Erkek & 50,5 & 45,1 & 49,5 & 46,2 & 52,9 & 42,3 \\
\hline -Kadın & 14,4 & 16,8 & 18,6 & 20,5 & 4,7 & 7,9 \\
\hline $\mathbf{5 5 - 6 4}$ & 24,7 & 19,8 & 26,6 & 21,9 & 21,3 & 15,7 \\
\hline -Erkek & 39,9 & 31,5 & 39,0 & 32,0 & 41,6 & 30,6 \\
\hline -Kadın & 10,7 & 8,5 & 14,8 & 12,1 & 3,1 & 2,0 \\
\hline $\mathbf{6 5 +}$ & 10,3 & 9,3 & 9,8 & 8,7 & 10,9 & 10,0 \\
\hline -Erkek & 20,5 & 17,9 & 17,7 & 15,8 & 23,7 & 20,5 \\
\hline -Kadın & 2,4 & 2,6 & 3,8 & 3,5 & 0,6 & 1,2 \\
\hline
\end{tabular}

Kaynak: Küresel Yetişkin Tütün Araştırması, 2008, 2012.

Not: Tablolar arası rakamlarda yuvarlamadan dolayı farklılıklar olabilir.

Tablo 2'de yer alan yaş gruplarına ilişkin 2008 ve 2012 Küresel Yetişkin Tütün Araştırması verilerine göre aşağıdaki sonuç ve değerlendirmelere ulaşmak mümkündür;

-Yaş gruplarına göre en yüksek sigara kullanan grup 25-34 yaş grubudur. Bu bulguya göre sigara ile mücadelenin özellikle 15-24 yaş grubundaki gençlerin hedef alması gerekmektedir. Bu yaş grubunda gençlerin sigaraya başlaması engellenebilir ya da içenlerin bırakmaları sağlanabilirse önemli bir başarı elde edilmiş olabilecektir.

- Kadınlarda en yüksek sigara içme oranı 35-44 yaş grubunda iken erkeklerde en yüksek sigara içme oranı 25-34 yaş grubundadır. 
-Erkeklerde tüm kategori ve gruplarda 2008'den 2012'ye sigara içme oranında düşüş yaşanmıştır. Cinsiyete göre değerlendirildiğinde erkeklerde kadınlara göre daha olumlu gelişmeler yaşandığı görülmektedir.

-2008-2012 Döneminde kadınlarda sigara içme oranında genel olarak bir düşüş yaşanmış olmasına rağmen; yaş grupları itibariyle değerlendirildiğinde Türkiye geneli için, 35-44, 45-54 ve 65+ yaş grubunda sigara içme oranının yükseldiği görülmektedir. Bu dönemde kadınlarda kentte 35-44 ve 45-54; kırda 25-34, 45-54 ve 65+ yaş grubunda sigara içme oranının yükseldiği görülmektedir.

-35 yaş üzerindeki gruplarda yaş ilerledikçe sigara kullananların oranının düştüğü gözlenmektedir. Bu durum yaş ilerledikçe sağlık vb. nedenlerle sigara kullanma oranının düşmesinden kaynaklanmış olabilir.

$-65+$ yaş grubu hariç tüm yaş gruplarında genel olarak sigara içme oranı kentte kırdan daha yüksektir.

-35-44 ve 65+ yaş grubunda genel eğilimden farklı olarak kırda erkeklerde sigara içme oranı kentten yüksektir. Diğer yaş gruplarında erkeklerin sigara içme oranı beklentilere uygun biçimde kentte kırdan daha yüksektir.

\section{Türkiye'de Sigara Kullanımı ile Mücadelenin Yasal Çerçevesi}

Sigara kullanımını önlemeye yönelik alınan önlemler tütün kontrolü başlığı altında toplanmaktadır. Tütün kontrolü bireylerin tütün kullanımını ve tütün dumanına maruziyetini (pasif sigara içiciliğini) ortadan kaldırarak veya azaltarak sağlığını iyileştirmeyi amaçlayan bir takım arz, talep ve zarar azaltma stratejileridir (eczacibasisaglik.com.tr).

Türkiye'de tütün mamullerinin kullanımına yönelik mücadelenin geçmişi Osmanlı Devletine kadar uzanmaktadır. Osmanlı Devleti döneminde tütün kullanımı ile mücadele zaman zaman şiddetlenmekle birlikte tütün kullanılmaya devam edilmiştir. Örneğin, I.Ahmet döneminde şeyhülislam tütün kullanımının haram olduğu yönünde fetva yayınlamış ve sigara kullanımının yasaklanmasını istemiştir (Barış, 2012: 3). Ne var ki IV. Murat Döneminde uygulanan aşırı tedbirler bile sigara kullanımıyla mücadelede etkin sonuç alınmasını sağlayamamıştır.

Türkiye'de tütün kullanımı ile etkin yasal mücadelenin geçmişi ne yazık ki oldukça yenidir. Türkiye'de tütün kullanımını sınırlandırmak amacıyla ilk kapsamlı düzenleme 1996 yılında hayata geçirilmiştir. Sigara karşıtı yoğun mücadelelerin sonunda, tütün lobilerinin tüm çabalarına rağmen 7 Kasım 1996 tarihinde Tütün Mahsullerinin Zararlarının Önlenmesine Dair 4207 Sayılı Kanun çıkarılmıştır. Bu kanun ile sigara kullanımını özendirici reklam ve teşvik kampanyaları yasaklanmıştır. 
Sosyal Bilimler Dergisi 33

Sağlık, eğitim ve kültür hizmeti veren kurumlar ile kapalı spor salonlarında ve toplu taşımacılık yapılan her türlü taşıma araçları ile bunların bekleme salonlarında, kamu hizmeti yapan kurum ve kuruluşlardan beş veya daha fazla kişinin görev yaptığı kapalı mekânlarda sigara içilmesi yasaklanmıştır. Yine bu kanunla 18 yaşından küçüklere sigara ve tütün ürünlerinin satılması yasaklanarak çocukların korunması hedeflenmiştir. Kamuoyunu sigaranın zararları konusunda aydınlatmak üzere devlet ve özel televizyon kanallarına her ay doksan dakika sigara kullanımının zararlarını anlatan programları yayınlama mecburiyeti getirilmiştir.

2002 yılında tütün piyasasını izleme ve denetleme fonksiyonunu yerine getirmek üzere Tütün ve Alkol Piyasası Düzenleme Kurumu (TAPDK) kurulmuştur. TAPDK, sigara paketlerinin üzerindeki yer alacak sigara kullanımının zararlarını gösterir yazı ve resimleri belirlemektedir.

Dünya çapında sigara kullanımının giderek artması, çokuluslu şirketlerin DSÖ dünya çapında tütün ürünlerinin kullanımıyla mücadele etmek, sigaradan kaynaklanan sağlık sorunlarının artması tehdidinin önüne geçebilmek ve tütün kullanmamakla birlikte dumanından zarar görenleri durumunu düzeltmek amaciyla Tütün Kontrolü Çerçeve Sözleşmesini (TKÇS) hazırlayarak üye ülkelerin imzasına açmıştır. Tütün şirketleri tarafından gelişmekte olan ülkelerde pazar oluşturma stratejilerine karşı geliştirilen ve dünyada tütün kontrolüne yönelik ilk uluslararası anlaşma olan "Tütün Kontrolü Çerçeve Sözleşmesi", 21 Mayıs 2003 tarihinde, Cenevre'de Dünya Sağlık Örgütü'nün 56. Dünya Sağlık Asamblesi'nde kabul edilmiştir. Sözleşme büyük ilgi görmüş ve kısa sürede pek çok ülke tarafından imzalanarak uygulanmaya başlanmıştır. Türkiye, Tütün Kontrolü Çerçeve Sözleşmesini 28 Nisan 2004 tarihinde imzalanmıştır. Sözleşme 25 Kasım 2004 tarihinde Türkiye Büyük Millet Meclisinin onayından sonra 30 Kasım 2004 tarihinde yürürlüğe girmiştir. Sözleşmenin yürürlüğe girmesi 4207 Sayılı Kanundan sonra Türkiye'de sigara ile mücadelede atılan en önemli adımdır. TKÇS vergiler, paketleme, tütün tarımı, sigaranın zararları konusunda bilgilendirme, küçüklerin sigaraya erişimi, sigara bırakma etkinlikleri, sigara reklâmı ve satış koşulları gibi geniş yelpazede düzenlemeler içeren bir sözleşmedir (Ergüder, 2008: 9; Uzun, 2010: 59). TKÇS Türkiye'nin bu sözleşmeyle ilgili taahhütlerini yerine getirmek amacıyla TAPDK tarafından 2005 tarihinde bir yönetmelik çıkarılmıştır.

Türkiye'de tütün kontrolü ile ilgili en önemli düzenleme 2008 yılında çıkarılan 5727 Sayılı Tütün ve Tütün Mamullerinin Zararlarının Önlenmesine Dair Kanundur. 19 Mayıs 2008'de uygulanmaya başlanan yasanın kapsamı 19 Temmuz 2009 Tarihinde 4207 Sayılı Tütün Maddelerinin Zararlarının Önlenmesine Dair Kanunda yapılan değişiklikle genişletilmiş 
kapalı mekânlarda (kahvehane, lokanta, kafe, bar, dinlenme tesisleri, vb.) sigara içmek yasaklanmıştır. Bu düzenlemeler Dünyada sigara ile mücadelede yeni bir anlayışı temsil eden Tütün Kontrolü ve Çerçeve Sözleşmesi çerçevesinde uygulamaya konulmuştur. Türkiye sigara ile mücadelede en katı önlemleri içeren bu yeni anlayışı hayata geçiren dünyada altıncı, Avrupa'da üçüncü ülke olmuştur.

Günümüzde artık sigara yasağının kapsamının genişletilmesinden çok sigaranın tamamen yasaklanmasına yönelik çabalar gündeme gelmektedir. Bazı ülkeler şimdiden sigara kullanımının yasaklanacağı yılı ilan etmeye başlamışlardır. Örneğin, Yeni Zelanda 2030, Finlandiya 2050 yılında sigarayı tamamen yasaklayacaklarını açıklamışlardır. Avustralya'da ise 2023 yılında yasaklamadan sigara içilmesinin sıfırlanacağ 1 öngörülmektedir (aksam.com.tr).

\section{Sigara Kullanımını Etkileyen Faktörler}

Sigaraya başlamayı etkileyen faktörler; sigara fiyatı, yaş, gelir düzeyi, işgücüne katılım (Stewart, 1993: 160-163), meslek, cinsiyet, sigara reklamı, eğitim düzeyi, erkek ya da kız kardeşin sigara kullanması, akran ve arkadaşların sigara kullanması, anne ya da babanın sigara kullanması, anne babanın ayrı yaşaması, sigaranın zararları hakkında olumsuz bir düşüncenin yeterince yerleşmemiş olması, ülkenin ya da ikamet edilen yerleşim biriminin gelişmişlik düzeyi olarak sayılabilir.

Yapılan araştırmalarda sigaraya başlamadaki en önemli faktörlerin; ebeveynlerin sigara kullanması ve sigara ile ilgili tutumları ile arkadaşların (akranların) ve kardeşlerin sigara kullanması olduğu belirlenmiş̧tir (McDonald, 1993: 284).

\subsection{Gelişmişlik Düzeyi ve Sosyo-ekonomik Farklılıklar}

Çeşitli ülkelerde öğrenciler üzerinde yapılan çalışmalarda, birbirinden çok farklı sigara içme prevalansı değerleri bulunmuştur. Sigara içme sıklığının değişimi konusunda da ülkeler, bölgeler ve toplum grupları arasında çeşitli farklılıklar vardır. Genel olarak, sigara içme sıklığının gelişmiş ülkelerde azaldığı, gelişmekte olan ülkelerde ise artmaya devam ettiği bilinmektedir (Aykut vd., 2009: 130).

Ekonomik refah düzeyinin yükselmesi ile gelişmiş ülkelerde sigara tüketimi azalırken gelişmekte olan ülkelerde sigara tüketimi artmaktadır. Türkiye'de de benzer bir eğilim söz konusudur; gelir ve dolayısıyla ekonomik refah düzeyi yükseldikçe sigara tüketimi artmaktadır (Dikmen, 2005: 12). Şengül; Adana İlinde kadınların sigara tüketimini etkileyen 
faktörleri araştırdığı çalışmada; gelirdeki artışın sigara içme olasılığını artırdığı bulgusuna ulaşmıştır (Şengül, 1999: 114).

Çok sayıda çalışma sosyo-ekonomik farklılıklarla sigara kullanma oranı ve kullanılan sigara miktarı arasında güçlü kanıtlar olduğunu ortaya koymuştur. Düşük sosyo-ekonomik sinıflarda yer alan bireylerde sigara kullanma oranı ve tüketilen miktarının daha yüksek olmasının yanı sıra sigaradan kaynaklanan kanser ve diğer öldürücü hastalıklardan dolayı daha fazla ölüm oranına rastlanıldığı da ortaya konulmuştur. Sağlık hizmetlerine ulaşmadaki eşitsizlikler de dikkate alındığında, alt sosyo-ekonomik grupta yer alanların sigara kullanmasının diğer sosyo ekonomik gruplara göre sigaranın öldürücü etkilerini önemli derecede artırdığı söylenebilir (OECD, 2011: 50).

Sigara kullanımı kır ve kentsel alan arasında da farklılık göstermektedir. Türkiye'de kırsal kesimde sigara kullanma daha çok erkeklere özgü bir davranış iken, kentlerde kadınlar da sigara içenler arasında yer almaktadır.

Bir ülkede kırsal kesimden kentlere göçün artması, kentleşmenin hızlanması da sigara tüketimini etkilemektedir. Ekonomik anlamda kentleşme, tarım ve hayvancılıkla iştigal eden nüfusun sanayi ve hizmetler sektörüne kaymasına neden olur. Kentleşme sosyal ve kültürel açıdan değişimlere neden olur. Yapılan araştırmalar kentleşmenin sigara tüketiminin azalmasına yol açtığını göstermektedir. Türkiye için yapılan çalışmalarda da benzer sonuçlara ulaşılmıştır (Dikmen, 2005: 8, 13).

\subsection{Cinsiyet}

Sigara içmenin bazı ülkelerde kadınlar için uygun olmayan bir davranış olarak kabul edilmesi kadınlarda sigara kullanma oranının düşük olmasında bir etken olarak devreye girmektedir. Sigara kullanma konusunda kadınlara yönelik var olan bu tutum üniversitede okuyan kız öğrencilerinde sigara içme oranının düşük olmasının da kaynağı olabilir. Bu kültürel nedenlerden dolayı, bazı ülkelerde sigara içen kız öğrencilerin bir kısmının araştırma sırasında sigara içtiğini gizlemiş olması da söz konusu olabilir (Aykut vd., 2009: 132).

Sigara içmenin kadınlar için kabul edilebilir bir davranış olmadığı ya da erkeklere göre daha az kabul edilebilir bir davranış olduğu yönünde bir kanaatin varolduğu kültürel değerlere sahip toplumlarda kadınların sigara kullanma olasılığı erkeklerden daha düşüktür (Bilgiç vd., 2010: 749). Diğer taraftan kadının anne olması dolayısıyla gerek doğum öncesi gerekse doğum sonrası bebek sağlığı açısından sigara içmemesi gerektiği yönündeki 
tıbbi gerçekler de kadınlarda sigara içme oranını azaltan faktörler arasindadir.

Yapılan araştırmaların çoğunluğu sigara kullanma oranının erkeklerde bayanlara oranla daha yüksek olduğunu göstermektedir. Ancak son yıllarda bayanlarda da sigara kullanma oranının yükseldiği bilinmektedir. Ülkemizde 1997-1998 yıllarında yapılan bir çalışmada sigara içimindeki son durum ile geçen 8 yıl içindeki değişimler araştırılmıştır. Bu çalışmada sigara içiminde erkeklerde bir azalma gözlenirken, kadınlarda artış olduğu tespit edilmiştir (eczacibasisaglik.com.tr). Türkiye'de sigara alışkanlığını erkeklerde belirgin bir şekilde kadınlardan yüksektir. Bu durum, Küresel Yetişkin Tütün Araştırması sonuçlarında net bir şekilde görülmektedir.

Caliskan (2009: 192) yaptığı araştırmada, cinsiyetin sigara kullanma olasılığını önemli derecede etkilediği sonucuna ulaşmıştır. Caliskan'ın bulgularına göre cinsiyetin kadın olması sigara içme olasılığını \%14 düşürmektedir.

\subsection{Ergenlik (Yaş) ve Akran (Arkadaş Çevresinin) Etkisi}

Tüm kötü alışkanlıklarda olduğu gibi sigara kullanma konusunda da çevre ve akran etkisi belirleyici olmaktadır. Akran grubunda sigara içen arkadaşların varlığı durumunda; gençler kendilerine akran grubunda bir yer edinebilmek, kendini ispatlamak ya da grubun baskısına maruz kalmak suretiyle sigara içmeye başlamaktadırlar. Pek çok çalışmada gençlerin sigaraya başlamasındaki en önemli etkenin akran grubu içinde özellikle özendikleri arkadaşlarının sigara içmesi olduğu belirlenmiştir (Göksel vd., 2001: 53).

Genç erişkinler bağımlılık oluşturan sigara, alkol ve uyuşturucu madde kullanımı açısından en riskli grubu oluşturmaktadırlar. Ergenlik dönemi sigara kullanmaya başlamak için çok kritik bir dönemdir. Özellikle bu dönemde aile bireylerinin ve yakın akranların sigara kullanması sigaraya başlamada önemli bir etken olarak devreye girmektedir.

Sigaraya başlama yaşı toplumdan topluma, yerleşim alanının niteliğine, cinsiyet vb. faktörlere göre değişmekle birlikte, sigara içenlerin çoğunluğunun ergenlik döneminde sigaraya başladığı görülmektedir. Üniversite eğitimine geçişle birlikte gençler üzerindeki okul ve aile kontrolü büyük ölçüde ortadan kalkmaktadır. Harcamalar konusunda da üniversite öğrencileri lise öğrencilerine göre daha özgürdürler. Bu faktörler, üniversite öğrencilerinin sigaraya başlamasını kolaylaştıran etkenler olarak ortaya çıkabilmektedir (Aykut vd., 2009: 127). 
Sosyal Bilimler Dergisi 37

Ergenlik dönemi çoğunlukla okul ortamında geçtiği için bu konudaki çalışmalar daha çok okullarda, öğrenciler üzerinde yapılmaktadır. Akpınar ve diğerleri (2006) öğrencilerin sigara tüketimi ve sigaraya başlama nedenlerini araştırdıkları çalışmada 13-17 yaş aralığının en kritik dönem olduğu sonucuna ulaşmışlardır. Aynı çalışmada sigaraya başlamadaki en önemli etkenin yakın arkadaşların sigara içmesi olduğu bulgusu da elde edilmiştir. Ayrıca yakın arkadaşların sigara içme davranışına ilişkin tutumlarının da sigara içme olasılığ etkilediği sonucuna ulaşılmıştır. Benzer sonuçlar Ayık ve Diğerleri (2005) ile Göksel ve Diğerlerinin (2001) çalışmalarında da elde edilmiştir.

Burt ve Peterson'un (1998) yapmış oldukları çalışmada, sigara kullanıcılarının \%71'inin sigaraya 18 yaş veya altında başladığını ortaya koymuşlardır. Türkiye'de çalışmalarda da sigara kullananların büyük çoğunluğunun genç yaşlarda, ergenlik döneminde sigara kullanmaya başladığını ortaya koymaktadır (Ayık vd., 2005: 78). Bu sonuçlar dikkate alındığında; sigara kullanımı ile mücadele etmenin en etkili yolu, gençleri sigaranın zararları konusunda bilinçlendirmek, sigaraya başlamalarını önlemek için gerekli caydırıcı önlemleri en katı biçimde uygulamak ve bu yaşlarda sigara içenlerin sigarayı bırakmasını sağlamaktır.

Birçok araştırma, sigaraya başlama konusunda, sigara içen arkadaşların etkisinin aile bireylerinden daha önemli olduğunu göstermektedir. Üniversite gibi, arkadaşlıkların çok önemli olduğu ortamlarda, sigara içmek yerine içmemenin kabul gören ve özenilen bir davranış biçimi haline getirilebilmesi sigara ile mücadelede çok önemli olumlu sonuçlara yol açacaktır. Böylece, sigaraya başlama eğiliminde olan öğrencilerin bundan vazgeçmeleri ve sigara içmekte olanların da sigarayı terk etmeleri kolaylaşacaktır (Aykut vd., 2009: 127).

Yaş ilerledikçe sigaraya başlama olasılığı azalmaktadır. Yapılan çalışmalar gençlerin sigaraya başlama olasılığının yaşlılara göre daha yüksek olduğunu ortaya koymaktadır (Bilgiç vd., 2010: 751). Yaş ilerledikçe insanların belirli bir hayat tarzını benimsemiş olmaları nedeniyle yeni alışkanlıklar edinmeye daha az istekli olmaları gibi davranışsal faktörler yanında ilerleyen yaşlarda sağlık problemlerinin ortaya çıması da sigara tercihini azaltan bir faktör olarak etkili olabilmektedir.

\subsection{Ailede Sigara İçen Kimselerin Bulunması (Ebeveynlerin Sigara Kullanması)}

Aile içinde alkol, sigara ve uyuşturucu madde kullananların bulunmasının aile büyüklerini örnek alan gençlerin bu maddelere yönelimlerini arttırdığı bilinmektedir. 
Akpınar ve diğerleri (2006) öğrencilerin sigara tüketimi ve sigaraya başlama nedenlerini araştırdıkları çalışmada aile bireylerinin sigara içme davranışlarının sigara içme durumunu etkileyen önemli bir etken olduğunu belirlemişlerdir. Şengül'de (1999) Adana ilinde kadınların sigara tüketimini etkileyen faktörleri araştırdığı çalışmada hanehalkında sigara içenlerin bulunmasının sigara içme olasılığını artırdığı sonucuna ulaşmıştır (Şengül, 1999: 114).

Bireylerin içinde yaşadıkları ailenin yapısı da sigara tercihi üzerinde etkili olmaktadır. Geleneksel ailelerde birlikte yaşayan akrabalardan birisinin anne-baba, büyük anne-baba ya da kardeşlerden birisinin sigara kullanması sigara içme isteğini tetikleyebilmektedir (Bilgiç vd., 2010: 751).

Yapılan pek çok çalışmada gençlerin birlikte yaşadıkları anne, baba, kardeş ya da diğer aile büyüklerinin sigara kullanmasının sigaraya başlamada önemli bir özendirici olduğu bulgusuna ulaşılmıştır. Aile bireyleri arasında sigara içme tercihinde en fazla kardeşlerin birbirini etkilendiği görülmektedir (Göksel vd., 2001:53). Caliskan (2009: 193) da yaptığı çalışmada, bireyin birlikte yaşadığı kimseler arasında sigara içenlerin bulunmasının sigara kullanma olasılığı önemli derecede artırdığını belirlemiştir. Gençlerin sigara içme tercihi ile anne babanın eğitim düzeyi ile arasında anlamlı ilişki saptanan çalışmalarda bulunmaktadır. Ebeveynlerin eğitim düzeyi düştükçe çocukların sigara kullanma ihtimali yükselmektedir (Ayık vd., 2005: 77-79).

Yapılan araştırmalar Türkiye'de her yıl yaklaşık 750 bin çocuk ve gencin sigaraya başladığını, sigaraya başlamada en önemli etkenin özenti olduğunu göstermektedir (Dikmen, 2005: 2). Gençler kendilerine model olarak kabul ettikleri yetişkinlere özenerek sigaraya başlama kararı vermektedirler. Bu nedenle sigarayla mücadelede gençlerin örnek aldığı aile büyükleri, arkadaşları ve öğretmenler gibi toplumda saygınlığı olan kişilerin duyarlılığının artırılması da sigara ile mücadelede önemli bir faktördür.

\subsection{Sigara Fiyatı}

Sigara talebini etkileyen faktörlerden bir tanesi de sigara fiyatlarıdır. Yapılan çalışmalarda sigara fiyatındaki değişmeler karşısında göstertilen tepkilerin yaş gruplarına göre farklılaştığı görülmektedir. Bu çalışmalarda genel olarak ergenlik-gençlik dönemlerindeki bireylerin sigara fiyatındaki değişmelere tepkisinin daha yüksek olduğu, yaş ilerledikçe tepkinin şiddetinin azaldığı yönünde bulgulara ulaşılmıştır (Karagöz vd., 2010: 28).

Sigara fiyat esnekliği düşük olan bir maldır. Bu nedenle hükümetler vergi gelirlerini artırmak istediklerinde fiyat esnekliği düşük olan alkol, akaryakıt vb. diğer mallarla birlikte sigara üzerindeki özel tüketim vergileri 
Sosyal Bilimler Dergisi 39

ve katma değer vergisi oranlarını artırmaktadırlar. Fiyat esnekliğinin düşük olması nedeniyle talep edilen miktarda çok düşük bir azalma meydana gelmesine karşılık toplam hâsılatta dolayısıyla vergi gelirlerinde daha yüksek artışlar yaşanmaktadır. Bu özelliği nedeniyle sigara tüketimi ve satışının artması kamu maliyesi açısından olumlu sonuçlar doğurmaktadır. Belki de sigara üreticilerinin lobi faaliyetleri yanında sigara tüketiminin kamu maliyesi üzerindeki bu olumlu etkisi nedeniyle, hükümetler uzun süre sigarayla mücadele konusunda çok istekli ve kararlı bir tavır gösterememişlerdir.

Türkiye'de yapılan sigara talep tahmini çalışmalarında da sigaranın fiyat esnekliğinin düşük olduğu belirlenmiştir. Tansel (1993) 1960-1988 zaman serisi verileri ile yaptığı çalışmasında sigaranın talep esnekliğini kısa dönem için 0,21 ve uzun dönem için 0,37 olarak hesaplamıştır. Önder (2000) 1960-2000 dönemi zaman serisi verileriyle yaptığı çalışmada sigaranın talep esnekliğini 0,19 olarak bulmuştur. Önder TÜİK 1994 Hanehalkı Tüketim Harcamaları verilerini kullanarak tahmin ettiği modelde ise sigaranın fiyat esnekliğinin 0,41 olduğu sonucuna ulaşmıştır (Uzun, 2010: 26; Önder, 2002).

Önder 2002, Türkiye'de sigara fiyatlarındaki yükselmenin sigara içme olasılığını fazla etkilemediği daha çok sigara miktarını azalttığı sonucuna ulaşmıştır. Önder bu eğilimin özellikle düşük gelir gruplarında gözlendiğini belirlemiştir. Tahmin ettiği modelin sonuçlarına göre, sigara fiyatına yapılacak \%100'lük bir artış, sigara içenlerin sadece \%2,7'sinin sigarayı bırakması ile sonuçlanacaktır. Önder aynı çalışmada gelir seviyesi yükseldikçe sigaranın fiyat esnekliğinin azaldığı bulgusuna da ulaşmıştır (Önder, 2002: 3).

\subsection{Eğitim Seviyesi, Meslek ve İşsizlik}

Eğitim seviyesi yükseldikçe insanların daha bilinçli hareket etmeleri ve beşeri sermayelerinin önemli bir bileşeni olan sağlık durumları konusunda daha hassas davranmaları beklenir. Yapılan çalışmalar, özellikle gelişmiş ülkelerde eğitim seviyesi yükseldikçe diğer zararlı maddelerle birlikte sigara kullanımının düştüğünü göstermektedir.

İssiz kişilerin sigara içme olasılığı iş sahibi olanlara göre daha yüksektir. Çalışan insanların iş esnasında sigara içmek için yeterli fırsata sahip olmaması da sigara tüketimini azaltan bir unsur olarak devreye girebilmektedir (Bilgiç vd., 2010: 749). Özellikle sigara kullanımının yasak olduğu işyerlerinde çalışan kişilerin sigara tüketiminin diğerlerine göre daha düşük olması beklenir. 


\section{Araştırmanın Kapsamı; Veriler, Yöntem ve Analiz}

$\mathrm{Bu}$ çalışmada anket uygulanan örneklem kümesinin ana kütlesini Uşak Üniversitesi öğrencileri oluşturmaktadır. Araştırma, 2010 yılında kesitsel çalışma biçiminde uygulanmış olup, 2009-2010 öğretim yılında Uşak Üniversitesine bağlı fakülte, yüksekokul ve meslek yüksekokullarında eğitim görmekte olan yaklaşık 7000 öğrenci araştırmanın ana evrenini oluşturmaktadır. Ana kitle oranlarına dayalı kümelendirilmemiş tek aşamalı tesadüfi olasılık örneklemesi yöntemiyle belirlenen 754 öğrenciden oluşan örneklem kümesine anket uygulanmıştır. Örneklem kümesi belirlenirken, fakülte, yüksekokul ve meslek yüksekokullarındaki öğrenci sayıları, normal ve ikinci öğretime devam eden öğrenci sayıları, öğrencilerin sınıfları ile cinsiyet gibi faktörler dikkate alınmıştır. Örnekleme alınan öğrencilere araştırmacılar tarafından sınıflarında anket uygulaması yapılmıştır. Araştırma verileri, eksik bilgi içeren 50 anket elendikten sonra kalan $319^{\prime} \mathrm{u}$ erkek ve 385 ' $\mathrm{i}$ kı olmak üzere toplam 704 öğrenciye ait bilgilerden oluşmaktadır. Araştırma evrenine ilişkin bilgiler ekte Tablo 3 ve Tablo 4'te toplu olarak sunulmuştur.

\subsection{Araştırma Evreninin Demografik Özellikleri}

Örneklem kümesini oluşturan öğrencilerin demografik özellikleri Tablo 3'te gösterilmiştir. 
Tablo 3. Örneklem Kümesini Oluşturan Öğrencilerin Demografik Özellikleri

\begin{tabular}{|c|c|c|c|}
\hline & & Sayı & Oran (\%) \\
\hline \multirow{2}{*}{ Cinsiyet } & Erkek & 319 & 45 \\
\hline & K1z & 385 & 55 \\
\hline \multirow{2}{*}{ Eğitim Birimi } & Fakülte / Yüksek Okul & 530 & 75 \\
\hline & Meslek Lüksek Okulu & 174 & 25 \\
\hline \multirow{2}{*}{$\begin{array}{l}\text { Devam Ettiği } \\
\text { Program }\end{array}$} & Normal Öğretim & 464 & 66 \\
\hline & İkinci Öğretim & 240 & 34 \\
\hline \multirow{5}{*}{$\begin{array}{l}\text { Ailesinin } \\
\text { İkamet Ettiği } \\
\text { Yerleşim } \\
\text { Birimi }\end{array}$} & Köy-Kasaba & 118 & 17 \\
\hline & İlçe & 231 & 33 \\
\hline & İl Merkezi & 189 & 27 \\
\hline & Büyükşehir & 160 & 23 \\
\hline & Diğer & 6 & 1 \\
\hline \multirow{6}{*}{ Kaldığ } & Kredi ve Yurtlar Kurumu & 115 & 16 \\
\hline & Özel Yurt & 228 & 32 \\
\hline & Öğrenci Evi & 242 & 34 \\
\hline & Ailesinin Yanı & 73 & 10 \\
\hline & Evde Tek Başına & 21 & 3 \\
\hline & Diğer (Misafirhane, Otel, vb.) & 25 & 4 \\
\hline \multirow{3}{*}{$\begin{array}{l}\text { Aylik } \\
\text { Ortalama } \\
\text { Geliri }\end{array}$} & 500 TL'den Az & 470 & 67 \\
\hline & 500 TL ila 750 arası & 189 & 27 \\
\hline & 750TL ve üzeri & 45 & 6 \\
\hline \multirow{4}{*}{$\begin{array}{l}\text { Çalışma } \\
\text { Durumu }\end{array}$} & Çalışmıyor & 613 & 87 \\
\hline & Part Time Çalışıyor & 30 & 4 \\
\hline & Ara-Sıra iş Olduğunda Çalışıyor & 49 & 7 \\
\hline & Sürekli Çalışıyor & 12 & 2 \\
\hline
\end{tabular}

Not: Tabloda yer alan oranların toplamı yuvarlamalardan dolayı 100 olmayabilir.

Ankete katılan öğrencilerin $319^{\prime}$ u erkek, 385'i kızdır. Öğrencilerin \%75'i fakülte/yüksekokul, \%25'i meslek yüksekokulunda eğitim görmektedir. Öğrencilerin \%66'sı normal, kalanı ikinci öğretime devam etmektedir. Öğrencilerin \%50 ilçe ve daha küçük yerleşim birimlerinden, \%27'si il merkezinden, \%23'ü büyükşehirlerden Uşak'a gelmişlerdir. Öğrencilerin \%82'si kredi yurtlar kurumu, özel yurt ve öğrenci evi gibi arkadaşlık ilişkilerinin güçlü ve yoğun olarak etkili olduğu dolayısıyla 
sigara içme davranışını etkileme olasılığı yüksek ortamlarda barınmaktadır. Öğrencilerin gelir durumları dikkate alındığında Uşak Üniversitesi öğrencilerinin genel olarak orta ve alt gelir grubuna mensup ailelerin çocuklarından oluştuğu söylenebilir. Öğrencilerde bir işte çalışma oranı da Uşak kent merkezinde çalışma imkânının sınırlı olmasının da bir sonucu olarak hayli düşüktür. (Kapsamlı bilgi için bakınız Tablo 3)

Tablo 4. Sigara İçen Öğrencilere İlişkin Özellikler

\begin{tabular}{|c|c|c|c|}
\hline & & Sayı & Oran $(\%)$ \\
\hline \multirow{3}{*}{$\begin{array}{l}\text { Sigarayı İlk Kez Deneme } \\
\text { Yaşı }\end{array}$} & 13 Yaş Altı & 52 & 32 \\
\hline & $13-18$ & 96 & 59 \\
\hline & $18+$ & 16 & 10 \\
\hline \multirow{3}{*}{$\begin{array}{l}\text { Düzenli Olarak Sigaraya } \\
\text { İçmeye Başlama Yaşı }\end{array}$} & 13 Yaş Altı & 15 & 9 \\
\hline & $13-18$ & 120 & 73 \\
\hline & $18+$ & 29 & 18 \\
\hline \multirow{3}{*}{$\begin{array}{l}\text { Sigara İçmeye } \\
\text { Başladığında Devam Ettiği } \\
\text { Eğitim Basamağı }\end{array}$} & İlk Öğretim & 31 & 19 \\
\hline & Lise & 101 & 62 \\
\hline & Yüksek Öğretim & 32 & 20 \\
\hline \multirow[b]{2}{*}{ Sigarayı Bırakma İsteği } & Birakmak İstiyor & 121 & 74 \\
\hline & $\begin{array}{l}\text { Kullanmaya Devam } \\
\text { Etmek İstiyor }\end{array}$ & 43 & 26 \\
\hline \multirow{6}{*}{$\begin{array}{l}\text { Sigaraya Başlamada Etkili } \\
\text { Olan En Önemli Faktörler }\end{array}$} & Ailedeki Sigara İçenler & 21 & - \\
\hline & $\begin{array}{l}\text { Mahalle/Okuldaki/Ders } \\
\text { hane vb. Arkadaş } \\
\text { Çevresi }\end{array}$ & 75 & - \\
\hline & $\begin{array}{l}\text { Öğretmen vb. } \\
\text { Özendiğimiz Büyükler }\end{array}$ & 7 & - \\
\hline & Sinema/Spor Yıldızları & 2 & - \\
\hline & Stres, Sikıntı & 87 & - \\
\hline & Diğer & 23 & - \\
\hline \multirow{4}{*}{$\begin{array}{l}\text { En Yakın Üç Arkadaşın } \\
\text { Sigara İçme Durumu }\end{array}$} & Hiçbiri İçmiyor & 6 & 4 \\
\hline & Sadece Birisi İçiyor & 32 & 20 \\
\hline & İkisi İçiyor & 54 & 33 \\
\hline & Üçü İçiyor & 72 & 44 \\
\hline \multirow{2}{*}{$\begin{array}{l}\text { Aile Büyüklerinin Yanında } \\
\text { Sigara İçme Tutumu }\end{array}$} & Sigara İçmeyenler & 112 & 68 \\
\hline & Sigara İçenler & 52 & 32 \\
\hline \multirow{2}{*}{$\begin{array}{l}\text { Sınav Döneminde Sigara } \\
\text { Kullanımındaki Değişim } \\
\end{array}$} & Miktarı Artıranlar & 130 & 79 \\
\hline & Değiştirmeyenler & 34 & 21 \\
\hline
\end{tabular}




\begin{tabular}{|c|c|c|c|}
\hline \multirow{2}{*}{$\begin{array}{l}\text { Sigara Paketlerinin } \\
\text { Üzerindeki Uyarı Yazılı ve } \\
\text { Resimleri Sigara } \\
\text { Tüketimini Etkileme } \\
\text { Durumu }\end{array}$} & Etkilemez & 149 & 91 \\
\hline & $\begin{array}{l}\text { Kullanılan Miktarı } \\
\text { Azaltır }\end{array}$ & 15 & 9 \\
\hline \multirow{3}{*}{$\begin{array}{l}\text { Sigara Fiyatları } \\
\text { Yükseldiğinde Verilen } \\
\text { Tepki }\end{array}$} & Miktarı Azaltanlar & 45 & 27 \\
\hline & $\begin{array}{l}\text { Daha Ucuz Sigara } \\
\text { İçenler }\end{array}$ & 37 & 23 \\
\hline & $\begin{array}{l}\text { Aynı Miktarda İçmeye } \\
\text { Devam Edenler }\end{array}$ & 82 & 50 \\
\hline \multirow{2}{*}{$\begin{array}{l}\text { Son Bir Y1l İçinde Sigarayı } \\
\text { Bırakma Denediniz mi? }\end{array}$} & Evet & 109 & 66 \\
\hline & Hayır & 55 & 34 \\
\hline \multirow{2}{*}{$\begin{array}{l}\text { Kapalı Mekânlarda Sigara } \\
\text { Yasağı Tüketiminizi Nasıl } \\
\text { Etkiledi? }\end{array}$} & Etkilemedi & 121 & 74 \\
\hline & Miktarı Azalttı & 43 & 26 \\
\hline
\end{tabular}

Not: Tabloda yer alan oranların toplamı yuvarlamalardan dolayı 100 olmayabilir.

Sigara içen öğrencilerin \%32'si ilköğretim çağında iken (13 yaşından küçükken), \%59'u lise yıllarında, sadece $\% 10$ 'u ise daha sonraki dönemlerde ilk defa sigarayı denediklerini beyan etmişlerdir. Düzenli olarak sigara kullanmaya başlamada, diğer kötü alışkanlıkların edinilmesinde olduğu gibi en talihsiz dönem lise yıllarıdır. Sigara kullanan öğrencilerin \%80'ni liseden mezun olup üniversiteye adım attığında sigara kullandığını ifade etmektedir. Bu veri, sigara ile mücadelenin özellikle orta öğretim öğrencileri hedef alınarak yürütülmesi gerektiğini açıça ortaya koymaktadır. Sigara içen öğrencilerin \%20'si ise sigara kullanımına üniversite yıllarında başlamaktadır.

Sigara kullanan öğrencilerin \%74'ü sigarayı bırakmak istediğini ve \%66'sı son bir yıl içinde sigarayı bırakmayı denediğini beyan etmiştir ki bu veri sigara ile etkin mücadele yürütülmesi halinde olumlu sonuçlar alınabileceğine işaret etmektedir. Öğrenciler sigaraya başlamada en etkili faktör olarak birinci sıraya stresi ikinci sıraya arkadaş/akran etkisini, üçüncü sıraya aile içinde sigara kullananların bulunmasını koymaktadır.

Ankette elde edilen çok ilginç bir veri ise sigara içen öğrencilerin en yakın arkadaşlarının sadece \%4'ünün sigara içmeyenlerden oluşmasıdır. Bu veri de sigaraya başlama ve kullanımını sürdürmede arkadaş/akran etkisinin çok önemli bir faktör olduğunu açıkça ortaya koymaktadır. Öğrencilerin \%32'sinin aile büyüklerinin yanında sigara kullanabildiğini 
beyan etmesi Türk aile yapısının ciddi bir değişim geçirdiğini göstermektedir. Sınav döneminde sigara kullanımının artması stres etkisinin önemli olduğunu teyit etmektedir. Öğrencilerin \%91'i sigara paketlerinin üzerindeki uyarı resim ve yazılarından etkilenmediğini ifade etmiştir. Bu veri paketlerle ilgili düzenlemelerin başlangıçta etkili olsa bile daha sonra kanıksanarak etkisiz hale geldiğini göstermektedir. Sigara fiyatlarındaki yükselmenin sigara kullanımı üzerinde -öğrencilerin gelirleri kısıtlı olduğu için- bir miktar etkili olduğu görülmektedir. Öğrencilerin \%26's1 sigara yasağının kapsamının genişletilerek kapalı mekânlarda sigara kullanımının yasaklanmasının içtikleri sigara miktarını düşürdüğünü ifade etmektedir. Bu sonuç, sigara kullanımı ile ilgili mekânsal yasakların kapsamının genişletilmesinin yararlı olacağına işaret etmektedir.

\subsection{Anket Verilerinin Ekonometrik Analizi}

Verilerin ekonometrik analizinde; öğrencilerin sigara kullanıma olasılığını etkileyen faktörleri tahmin etmek amacıyla benzer çalışmalarda sıklıkla tercih edilen ikili logit model tercih edilmiştir. Model oluşturulurken çok sayıda faktör bağımsız değişken olarak denenmiş, iktisadi, istatistiki ve ekonometrik kriterler esas alınarak modelin en son hali oluşturulmuştur.

Modelde kullanılan değişkenler:

Bağımlı Değişken;

Sigara kullanımını etkileyen faktörleri belirlemek amacıyla tahmin edilen ikili logit modelin bağımlı değişkeni;

$$
Y_{1}=\left\{\begin{array}{l}
1 \text { Birey sigara kullanmaktadır. } \\
0 \text { Birey sigara kullanmamktadır. }
\end{array} \quad\right. \text { olmak üzere, sigara }
$$

kullanma durumunu temsil eden iki değerli yapay bağımlı değişkendir.

\section{Bağımsız Değişkenler:}

Cinsiyet:

$\mathrm{D}_{1}= \begin{cases}1 & \text { Erkek } \\ 0 & \mathrm{~K} 1 \mathrm{z}\end{cases}$

Öğrencinin Ailesinde Sigara İçenlerin Varlığı:

$\mathrm{D}_{2}=\left\{\begin{array}{l}1 \text { Ailede sigara kullanan vardır. } \\ 0 \text { Ailede sigara kullanan yoktur. }\end{array}\right.$

Yakın Arkadaşların Sigara İçme Durumu:

$\mathrm{D}_{3}=\left\{\begin{array}{l}1 \text { Yakın arkadaşların çoğunluğu sigara içer. } \\ 0 \text { Yakın arkadaşlann çoğunluğu sigara içmez. }\end{array}\right.$ 


\section{Öğrencinin Alkol Alma Durumu:}

$\mathrm{D}_{4}=\left\{\begin{array}{l}1 \text { Öğrencialkolkullanmaktadır. } \\ 0 \text { Öğrencialkolkullanmamaktadır. }\end{array}\right.$

\section{Gelir}

$\mathrm{G}=$ Öğrencinin aylık geliri.

Modelin temel sınıfını; cinsiyeti kız, ailesinde sigara kullanan kimsenin bulunmadığı, yakın arkadaşlarının büyük çoğunluğu sigara içmeyen ve alkol kullanmayan öğrenciler oluşmaktadır.

Öğrencilerin sigara kullanımını etkileyen faktörlere ilişkin ikili logit modelin tahmin sonuçları Tablo 5'de yer almaktadır.

Tablo 5. Sigara Kullanıma Olasılığı Modelinin Tahmin Sonuçları

\begin{tabular}{ccccc}
\hline \hline Değişken & Katsayı & Standart Hata & Z-Değeri & Olasılık \\
\hline \hline Sabit Terim & -3.680719 & 0.382107 & -9.632694 & 0.0000 \\
$\mathrm{D}_{1}$ & 0.545989 & 0.222376 & -2.455252 & 0.0141 \\
$\mathrm{D}_{2}$ & 0.644557 & 0.222027 & 2.903050 & 0.0037 \\
$\mathrm{D}_{3}$ & 1.455167 & 0.238022 & 6.113587 & 0.0000 \\
$\mathrm{D}_{4}$ & 1.113478 & 0.216358 & 5.146454 & 0.0000 \\
$\mathrm{G}$ & 0.002000 & 0.000555 & 3.604826 & 0.0003 \\
\hline \hline
\end{tabular}

LR İstatistiği $(5 \mathrm{df})=184.5252$ McFadden $R^{2}=0.241$ Gözlem Sayıs1 $=704$

Önsel olarak; modelin tüm değişkenlerine ait katsayıların pozitif işaretli olması beklenmekteydi. Tahmin sonuçlarına göre; modele dâhil edilen tüm katsayılar önsel beklentileri karşılamakta olup, tamamı \%5 önem düzeyinde istatistikî bakımdan anlamlıdır. Yapılan tahmin sonucunda; öğrencinin cinsiyetinin, ailesinde sigara kullanan bireylerin varlığının, yakın arkadaşları arasında sigara içenlerin bulunmasının, gelir düzeyinin yükselmesinin ve öğrencinin alkol kullanmasının sigara kullanma olasılığını önemli derecede etkileyen faktörler olduğu belirlenmiştir.

Yapılan tahmin sonucu aşağıdaki bulgulara ulaşılmıştır:

- Kız öğrencilerin sigara içme olasılığı erkeklerden daha düşüktür.

- Öğrencilerin ailelerinde sigara içenlerin bulunması sigara kullanma olasılığını yükseltmektedir.

- Öğrencilerin yakın arkadaşlarının çoğunluğunun sigara kullanması sigara kullanma olasılığını artıran bir etkendir.

- Öğrencilerin alkol kullanmaları sigara içme olasılığını yükseltmektedir. Bu açıdan bakıldığında; bireylerin sağlıklarını tehdit eden 
tüm olumsuz alışkanlıklarla mücadelenin birlikte yürütülmesi gerektiği söylenebilir.

- Öğrencilerin gelir seviyesinin yükselmesi de sigara alışkanlığını olumsuz etkileyen faktör arasında yer almaktadır.

İkili logit modelin tahmin parametrelerinden hareketle, bağımsız değişkenlerin bağımlı değişken üzerindeki etkilerine ilişkin olasılık değerlerini hesaplamak mümkündür. Tahmin sonuçlarından yapılan hesaplamaya göre;

- Temel sinıfta yer alan bir öğrencinin sigara içme olasılığ $1 \% 2,5^{\prime}$ tir.

- Öğrencinin yakın arkadaşlarının çoğunluğunun sigara içiyor olması sigara kullanma olasılığını \%10 artırmaktadır. Bu sonuca göre; bir öğrencinin sigara içme olasılı̆̆ üzerinde en olumsuz etki arkadaş faktörüne aittir.

- Öğrencinin alkol kullanması sigara içme olasılığını $\%$ artırmaktadır.

- Öğrencinin ailesinde sigara içenlerin bulunması sigara içme olasılığını \%4,6 artırmaktadır.

- Öğrencinin cinsiyetinin erkek olması, kızlara göre sigara içme olasılığını \%1,5 artırmaktadır.

\section{Sonuç}

$\mathrm{Bu}$ çalışmada üniversite öğrencilerinin sigara içme davranışlarını etkileyen değişkenler araştııılmıştır. Çalışmada kullanılan veriler Uşak Üniversitesi öğrencilerine uygulanan anket çalışmasından elde edilmiştir. Tahmin edilen modelin sonuçlarına göre; öğrencilerin cinsiyeti, alkol kullanma durumları, ailelerinde ve arkadaş çevrelerinde sigara içenlerin bulunması ve gelir düzeyleri sigara kullanma durumları üzerinde önemli derecede etkili olan faktörler olarak ortaya çıkmıştır. Tahmin bulgularına göre; erkek öğrencilerin sigara içme olasılığı kızlardan daha yüksektir ve öğrencilerin eline geçen gelir miktarının yükselmesi sigara kullanma olasılığını artırmaktadır. Diğer üç faktör öğrencilerin sigara kullanma olasılığını artırmaktadır.

Ekonometrik analizde ikili logit model kullanılmıştır. Bu modelin bir özelliği açıklayıcı yapay değişkenlerin açıklanan değişken üzerindeki etkilerinin olasılık değerlerini hesaplamaya imkân vermesidir. Bu modelin tahmin parametrelerinden yapılan hesaplamaya göre; öğrencilerin arkadaş çevrelerinde sigara içenlerin bulunması \%10, alkol kullanmaları \%7 ve ailelerinde sigara içen bireylerin bulunması $\% 4,6$ oranında sigara kullanma olasılığını artırmaktadır. Öğrencinin cinsiyetinin kız olması, erkeklere göre sigara içme olasılı̆̆ını \%1,5 düşürmektedir. 
Çalışmada elde edilen bulgular, önsel beklentilerle uyumlu çıkmıştır. Başlangiçta model oluşturulurken en önemli faktörün akran ve aile etkisi olacağı öngörülmüş idi. Bu amaçla anket formunda bu faktörleri ölçmeye yönelik almaşık sorular yöneltilmişti. Ulaşılan sonuçlar sigara ile mücadelenin aile de başlayarak, akranların bir arada bulunduğu okul ve diğer sosyal ortamlarda sürdürülmesinin en etkili yöntem olacağını göstermektedir.

\section{Kaynakça}

AKPINAR E., YOLDAŞCAN E., SAATÇİ E. (2006). “The Smoking Prevalence And The Determinants Of Smoking Behavior Among Students in Cukurova University, Southern Turkey". West Indian Medical Journal, 55(6): 414-9.

ATILGAN Y., GÜRKAN S., ve ŞEN E. (2008). "Hanemizde Çalışan Personelin Sigara İçme Durumu ve Etkileyen Faktörler", Türk Toraks Dergisi, Cilt 9, Say1 4, 160-166.

AYIK S.Ö. vd., (2005), “Lise Öğrencilerinin Sigara Alışkanlıklarını Etkileyen Faktörler", İzmir Göğüs Hastanesi Dergisi, Cilt 19, Sayı: 3, 77-82.

AYKUT M. vd. (2009). "Erciyes Üniversitesi Öğrencilerinde Sigara İçme Durumunun 1985 - 2005 Yilları Arasındaki Değişimi", Erciyes Tip Dergisi 31(2), 126-134.

BARIŞ Y. İ., "Tütün Kullanımının Tarihçesi", www.toraks.org.tr/userfiles/file/tutun_kullanımının_tarihcesi_baris. pdf, (Erişim Tarihi: 28 Kasım 2012)

BILGIC A., FLORKOWSKI W. and AKBAY C. (2010). "Demand for Cigarettes in Turkey: An Application of Count Data Modelss", Empirical Economics, Vol. 39, Issue 3, 733-765.

BURT, R.D. \& PETERSON, A.V. (1998). "Smoking Cessation Among High School Seniors". Preventive Medicine, Vol. 27, 319-327.

CALISKAN, S. (2009). "The Factors that Affect Smoking Probability and Smoking Expenditures in Turkey", Serbian Journal of Management, Vol. 4 (2), $183-202$.

CRAMER, J.S. (2003). Logit Models From Economics and Other Fields, Cambridge University Press, Cambridge.

DİKMEN N., “Türkiye'de Sigara Tüketimi ve Tüketimi Etkileyen Değişkenler Üzerine Bir Model Çalışması", Atatürk Üniversitesi, Iktisadi ve İdari Bilimler Dergisi, Cilt: 19 Nisan 2005 Sayı: 1, 1-19.

ERGÜDER T. (2008), Tütün Kontrolü Çerçeve Sözleşmesi, Ankara. 
GÖKSEL, T., CíRIT M. ve BAYINDIR Ü. (2001). "İzmir İli Lise Öğrencilerinin Sigara Alışkanlığını Etkileyen Faktörler", Toraks Dergisi, Cilt 2, Sayı 3, 49-53.

KARAÖZ M., ALBENİ M. ve BÜYÜKTATLI F. (2010). "Yasal Düzenlemelerin Sigara Tüketimi Üzerindeki Etkileri" Alanya İşletme Fakültesi Dergisi 2/2, 19-36.

KÜRESEL YETIŞKINN TÜTÜN ARAŞTIRMASI, 2008.

KÜRESEL YETIŞKİN TÜTÜN ARAŞTIRMASI, 2012.

ONDER, Z. (2002). The Economics of Tobacco in Turkey: New Evidence and Demand Estimates. World Bank, Economics of Tobacco Discussion Papers, No. 2.

"Sigaranın Tarihçesi", www.fatihbasaran.com/sigaranin-tarihcesidunya $\%$ e2\%80\%99da-ve-turkiye $\%$ e2\%80\%99desigara/\#ixzz1n6crxtvt (Erişim Tarihi: 28 Kasım 2012).

"Sigarayı bırakın, hayatınız değişsin" www.eczacibasisaglik.com.tr/onubirakin-hayatiniz-degissin--mID11.html (Erişim Tarihi: 28 Kasım 2012).

"Yasak, Hem Sağliğa Hem Ekonomiye Yaradı" http://www.aksam.com.tr/yasak,-hem-sagliga-ekonomiye-yaradi-58797h.html (Erişim Tarihi: 3 Ağustos 2011). 